\title{
Ovarian dysgerminoma: a case report
}

\section{Shamrao Ramji Wakode, Varsha Narayana Bhat*}

Department of Obstetrics and Gynaecology, Dr S. C. G. M. C. Nanded, Maharashtra, India

Received: 21 January 2021

Accepted: 02 March 2021

\section{*Correspondence:}

Dr. Varsha Narayana Bhat,

E-mail: chvarshanbhat@gmail.com

Copyright: (c) the author(s), publisher and licensee Medip Academy. This is an open-access article distributed under the terms of the Creative Commons Attribution Non-Commercial License, which permits unrestricted non-commercial use, distribution, and reproduction in any medium, provided the original work is properly cited.

\section{ABSTRACT}

An ovarian dysgerminoma is a rare, malignant tumour occurring in young women, accounting for $1 \%$ to $2 \%$ of all primary ovarian neoplasms. A 22 years old female presented with 6 months of amenorrhea and lump in the abdomen. Her physical examination was remarkable with 36 weeks sized huge abdominal mass. Subsequent computed tomography revealed $22 \times 23 \times 32.4 \mathrm{~cm}$ mixed density lesion in pelvi-abdominal region and multiple paraaortic and mesenteric lymph node with gross pleural effusion. On further evaluation raised beta-hcG and LDH were noted and hence dysgerminoma was suspected. Total abdominal hysterectomy with right salpingo-ophorectomy with resection of tumour mass with partial omentectomy and lymphadenectomy was performed. Histopathology reports were suggestive of dysgerminoma.

Keywords: Dysgerminoma, Malignant ovarian tumor, Surgical intervention

\section{INTRODUCTION}

Ovarian germ cell tumours are derived from primordial germ cells of the ovary. They can be malignant or benign and they comprises about $30 \%$ of ovarian neoplasms and $3 \%$ of all malignant ovarian neoplasms. ${ }^{2}$ It arises by malignant transformation of the primodial germ cells and in some cases may occur on anomalies of genital tract such as gonadal dysplasia. ${ }^{3}$ They usually arise in young women between 10 and 30 years of age. These tumors grow rapidly, and present as abdominal pain and large tumour mass in the abdomen. ${ }^{4}$

Malignant GCT's are being classified into subgroups, the most common of it is dysgerminoma. Most common mode of spread is through lymphatic system into paraaortic lymphnode. In cases of unilateral encapsulated unruptured tumour conservative surgery is the treatment of choice. In advanced stages of the tumour, radical surgical procedure followed by chemotherapy will be done. The five years survival rate of tumour in stage 1 is $80-90 \%$. $^{5,6}$

\section{CASE REPORT}

A 22 years old female with para1 live1 had come to the ANC OPD with amenorrhea and lump in the abdomen since last 6 month with chief complaint of pain in the abdomen requesting for routine antenatal sonography for fetal well-being. History of significant weight loss was present. She was pale and cachexic and on clinical examination a 36 weeks size hard mass arising from pelvis which was immobile. Transabdominal and transvaginal sonography suggestive of normal sized uterus with absent gestational sac and a heterogenous large mass anterior to uterus was noted. As a part of further evaluation computed tomography demonstrated well defined heterogenous mixed density lesion of $22 \times 24 \times 32.4 \mathrm{~cm}$ (APXTXCC), bilateral ovaries were not visualized separately, uterus was normal with multiple subcentric lympohnode in paraaortic and mesenteric region with mild ascites and gross bilateral pleural effusion. Additional laboratory studies were drawn with raised LDH (600U/L) and beta-hcG $(10 \mathrm{mIU} / \mathrm{mL})$. Based on patients age, laboratory values and radiological findings diagnosis of dysgerminoma was made. Pleural 
tapping showed elevated protein in the pleural fluid and with no LDH activity or bacilli. After correction of anaemia with 2 pint blood transfusion and surgical fitness she underwent exploratory laparotomy with total abdominal hysterectomy with right salpingo-opherectomy with resection of tumour mass with partial omentectomy with lymphadenectomy was performed. The pathological diagnosis was turned as dysgerminoma. The tumour was encapsulated. Tumour was weighing $7.5 \mathrm{~kg}$ with maximum gross dimension of the tumour was $30 \mathrm{~cm}$. The removed tumour was sent for histopathological analysis. A peritoneal washing was collected for cytological analysis. seen and no macroscopically visible secondary deposits were visible vascular infiltration was not found.

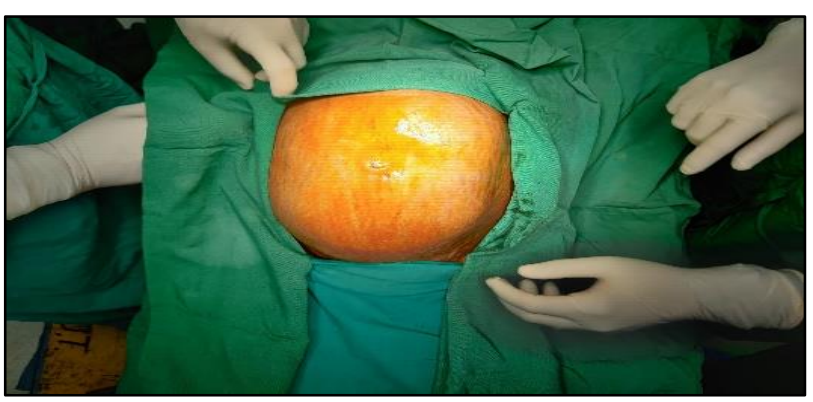

Figure 1: Preoperative photography showing 36 weeks abdominal mass.

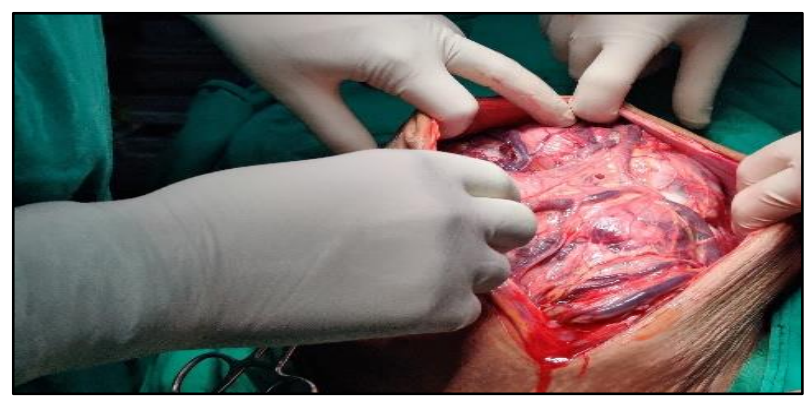

Figure 2: Highly vascular tumour.

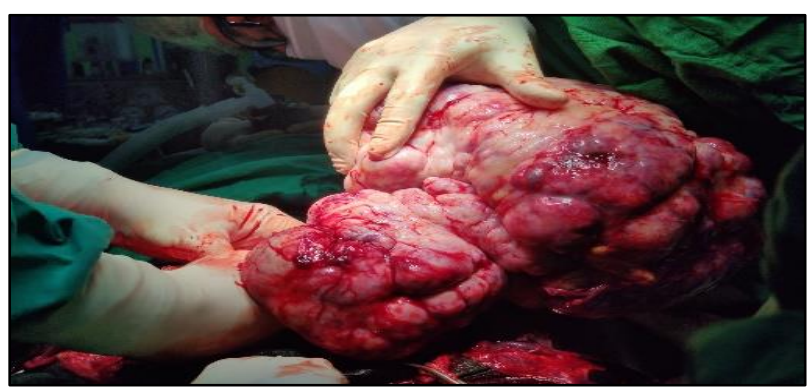

Figure 3: Large right ovarain tumour-seperated from omentum and large vessels.

Peritoneal washing for malignant cells was negative. The consulting team decided to carry out adjuvant chemotherapy and hence referred to higher centre for the same. Postoperative CT scan suggestive of no obvious lesion in the pelvic bed but metastatic retroperitoneal lymphadenopathy were noted. Post-operative tumour markers were done and elevated (LDH-294U/L, betaHCG-2.95mIU/mL) but were reduced as compare to preoperative values. According to the protocol patient was planned for 3 cycles of BEP (Bleomycin, etoposide, cisplatin) at higher centre.

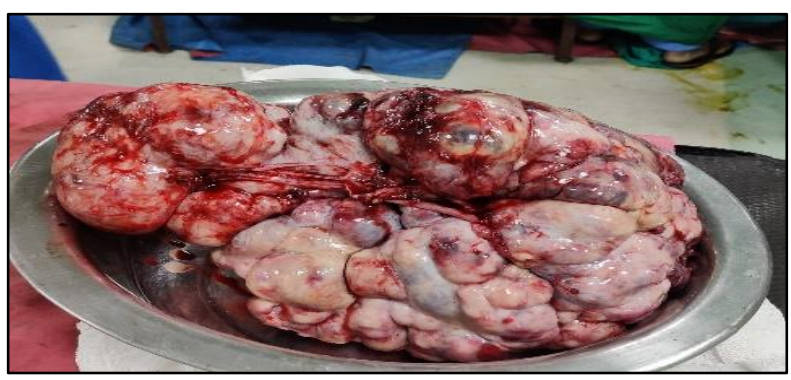

Figure 4: Gross excised specimen weighing $7.5 \mathrm{~kg}$.

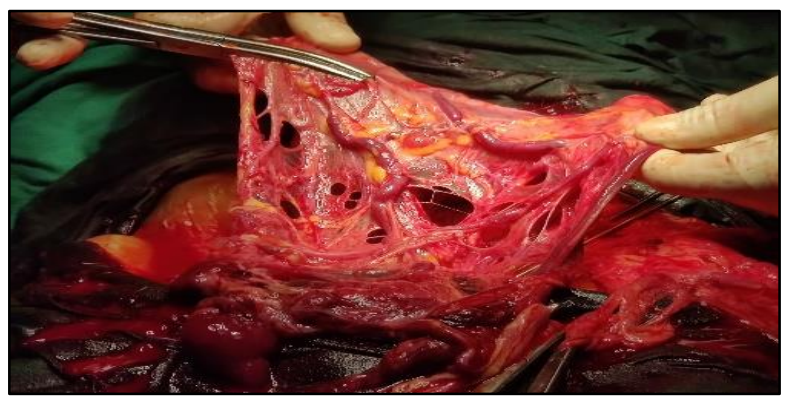

Figure 5: Omental dissection-partial omentectomy done.

\section{DISCUSSION}

Dysgerminoma is the most common type of malignant germ cell tumour, comprising of $1-2 \%$ of all malignant ovarian tumours. In most cases, it occurs at the ages of 20 and 30 as our patient was 22 years old. The tumour most often occurs unilaterally in about $80-85 \%$ of all cases, as was the case in our patient. Dysgerminomas tend to spread by the perirectal lymphatic system to lymph nodes near the aorta as our patient who had paraaortic lymphnode involvement. ${ }^{7}$ The main clinical feature is rapid growth of the tumour and symptoms may persist from one to six months prior to diagnosis. The first symptom is pain in the abdomen followed by abdominal mass. ${ }^{8}$ Most commonly it spreads through the lymphatic para aortic in the lymph nodes, and haematogenous spread may take place in the advanced stages of the disease. Tumour marker may aid in the diagnosis and postoperative management of dysgerminoma. Elevated beta-HCG $(10 \mathrm{mIU} / \mathrm{mL})$ and LDH $(600 \mathrm{U} / \mathrm{L})$ were documented in this case report as seen in most of the cases of dysgerminoma. ${ }^{9-12}$ There were no pathological findings on the liver, stomach, small and large intestine, omentum or parietal peritoneum on naked eye examination in our patient. The cytological finding of the ascitic fluid taken from the abdomen was negative for tumour cells. Patient management is focussed on treating the tumour while preserving the fertility. While in 
advanced stages of the disease such as Ib and above, radical surgical approach can be done which includes hysterectomy with bilateral salpingo-opherectomy, lymphadenectomy with omentectomy as done at our centre. ${ }^{13}$ Postoperative chemotherapy consisting of BEP were applied to this patient as it is considered as gold standard and widely accepted. ${ }^{14,15}$

\section{CONCLUSION}

Reproductive aged group women presenting with lower abdominal pain and rapidly growing mass with recurrent culture negative UTIs ovarian tumours should be considered and should be evaluated aggressively to rule out malignancies at the earliest. Dysgerminoma represent a distinct category with excellent response to chemotherapy and radiotherapy. Postsurgical clinical surveillance can be planned for patient at low risk to prevent secondary malignancies, steriliry, and gonadal dysfunction associated with pelvic radiotherapy but careful followup is required to ensure early detection of recurrence. Patients education on compliance with treatment plan and specialist follow-up will definitely improve their outcome in postoperative period.

Funding: No funding sources

Conflict of interest: None declared

Ethical approval: Not required

\section{REFERENCES}

1. Smith HO, Berwick M, Verschraegen CF, Wiggins C, Lansing L, Muller CY, et al. Incidence and survival rates for female malignant germ cell tumors. Obstet Gynecol. 2006;107(5):1075-85.

2. Cancer survival by stage at diagnosis for England (experimental statistics): Adults diagnosed 2012, 2013 and 2014 and followed up to 2015; Office for National Statistics (ONS). 2015.

3. Yoon S, Park HG, Kuk JY, Oak SA, Park JH. A case of ovarian dysgerminoma with dysgenesis in 29-yearold woman with 46,XX karyotype. Korean J Obstet Gynecol. 2012;55(10):772-6.

4. Tangjitgamsol S, Hanprasertpong J, Manusirvithaya S, Wootipoom V, Thavaramara T, Buhachat R. Malignant ovarian germ cell tumors: clinicpathological presentation and survival outcomes. ActaObstetGynecol Scand. 2010;89(2):182-9.
5. Vicus D, Beiner M, Klachook S, Le L, Laframboise S, Mackay H. Purge dysgerminoma of the ovary 35 years on: A single institutional experiences. GynecolOncol. 2010:117(1):23-6.

6. Biswajit D, Patil CN, Sagar TG. Clinical presentation and outcome of pediatric ovarian germ cell tumor: A study of 40 petients. J Pediatric Hematol Oncol.2010;32(2):e54-e56.

7. Kumar S, Shah JP, Bryant CS, Imudia AN, Cote ML, AliFehmi R, et al. "The prevalence and prognostic impact of lymph node metastasis in malignant germ cell tumors of the ovary," GynecolOncol. 2008;110(2):125-32.

8. Lee IH, Choi CH, Hong DG, Song JY, Kim YJ, Kim KT.et al. Clinicopathologic characteristics of granulosa cell tumors of the ovary: a multicenter retrospective study. J GynecolOncol. 2011;22:18895.

9. Lu KH, Gershenson DM: Update on the management of ovarian germ cell tumors. J Reprod Med. 2005;50:417-425.

10. Husaini HAL, Soudy H, Darwish AED. Pure dysgerminona of the ovary: a single institutional experience of 65 patients. Med Oncol. 2012;29:29448.

11. Guerriero S, Testa AC, Timmerman D. Imaging of gynecological disease (6): clinical and ultrasound characteristics of ovarian dysgerminoma. Ultrasound Obstet Gynecol. 2011;37:596-602.

12. Baker PM, Oliva E. Germ cell tumors of the ovary. In, Nucci MR, Oliva E (eds): Gynecologic Pathology. London, Elsevier Churchill Livingstone. 2009;501-7.

13. Vicus D, Beiner M, Klachook S, Le L, Laframboise S, Mackay H. Purge dysgerminoma of the ovary 35 years on: A single institutional experiences. GynecolOncol. 2010;117(1):23-6.

14. Pautier P, Gutierrez-Bonnaire M, Rey A, Sillet-Bach I, Chevrean C, Kerbrat P, et al. Combination of bleomycin, etoposide, and cisplatin for the treatment of advanced ovarian granulosa cell tumors. Int $\mathbf{J}$ Gynecol Cancer. 2008;18:446-52.

15. Talukadar S, Kumar S, Bhatla N, Mathur S, Thulkar S, Kumar L. Neo-adjuvant chemotherapy in the treatment of advanced malignant germ cell tumors of ovary. Gynecol Oncol. 2014;132:28.

Cite this article as: Wakode SR, Bhat VN. Ovarian dysgerminoma: a case report. Int J Reprod Contracept Obstet Gynecol 2021;10:1704-6. 